DOI: 10.34185/1991-7848.itmm.2020.01.003

\title{
АНАЛІТИЧНЕ ДОСЛІДЖЕНЯ ВПЛИВУ КОНСТРУКЩІЇ СКЛАДЕНОГО СОПЛА НА ТЕРМОДИНАМІКУ ПРОЦЕСІВ ПРИ ПРОДУВЦІ ЗВЕРХУ У LD-КОНВЕРТЕРI
}

Голуб Т.С., к.т.н., Семикін С. І., к.т.н., с.н.с. Інститут чорної металургії ім. 3.І. Некрасова НАН України, Україна Анотація. У киснево-конвертерній ванні протікає складний комплекс явищ, серед яких процес взаємодії газового струменя окислювача з розплавом є первинним і визначальним фактором в проходженні фізико-хімічних і тепло- масообмінних процесів при плавці. 3 метою підвищення ступеня якісного засвоєння кисню дуття ванною запропоновано використання складеного сопла на базі коаксіального кільцевого. Аналітичне дослідження термодинамічного показника протікання реакцій - енергії Гіббса для умов використання складеного кільцевого сопла встановило можливість більш активного протікання всіх реакцій, що протікають у первинній реакційній зоні, а особливо реакцій, що відповідають за шлакоутворення та тепловий стан ванни. Отримані результати кореспондуються зі встановленими раніше на фізичних та високотемпературних дослідах ефектами у порівнянні 3 роботою звичайного чотирьох соплового наконечника: більш глибоким зануренням струменя газу у рідку ванну, активним засвоєнням вапна та підвищенням температури підфурменої зони.

\begin{tabular}{|c|c|c|c|}
\hline Ключові & слова: & КИСНЕВО-КОНВЕРТЕРНИЙ & ПРОЦЕС, \\
\hline ПРОДУВКА & ЗВЕРХУ, & СКЛАДЕНЕ & СОПЛО, \\
\hline
\end{tabular}

Принципи організації дуттьового режиму в даний час є однаковими для конвертерів різної ємності, тому в великовантажних конвертерах з верхньою продувкою через локальне розміщення дуття неминуче виникають складності в організації циркуляції металу по всьому об'єму ванни і ефективності засвоєння кисню дуття на процеси окислення основних компонентів розплаву [1-3]. Це в значній мірі впливає на інтенсивність протікання конвертерних процесів в цілому. Отже, актуальними є роботи і дослідження з розробки технічних i конструктивних рішень, спрямованих на підвищення 
International scientific and technical conference Information Technologies in Metallurgy and Machine building - ITMM 2020

енергоефективності засвоєння кисню ванною і збільшення частки кисню, що йде на прямі рафінувальні процеси.

3 метою підвищення ефективності засвоєння кінетичної енергії і окисного потенціалу струменя була запропонована нова конструкція наконечника фурми зі складеними соплами, що являють собою кільцеве сопло. Запропонована конструкція сопел була досліджена на холодній моделі 160-т кисневого конвертера 3 продувкою зверху в масштабі 1:30 із застосуванням води для імітації рідкого металу та високотемпературній 60-кг моделі, для яких параметри сопла: зовнішній діаметр кільцевого сопла $6,5 \cdot 10^{-3} \mathrm{M}$ i внутрішній діаметр 5,5 · $10^{-3}$ м. Робота дослідного варіанту сопла була порівняна 3 роботою наконечника 3 чотирма стандартними соплами (діаметр сопла $1,7 \cdot 10^{-3}$ м) еквівалентної сумарної площі. Було встановлено [4], що за результатами холодного моделювання струмінь газу, що витікає з кільцевого сопла, по осі поширення володіє більшим динамічним напором і глибше проникає в рідину у порівнянні зі струменем, що витікає з чотирьох соплового наконечника зі стандартними соплами. На високотемпературній моделі відмічено більш раннє запалювання плавки, активне засвоєння вапна та підвищення температури підфурменої зони на величину порядку 15 \%, при зіставленні з порівняльними продувками.

Метою даної роботи було визначення особливості впливу розроблюваної конструкції сопел на перебіг хімічних перетворень, які відбуваються в кисневому конвертері, шляхом проведення термодинамічного аналізу. Для оцінки ймовірності перебігу хімічних реакцій була використана енергія Гіббса $(\Delta \mathrm{G})$, яку було розраховано за формулою [1-2]:

$$
\Delta G=-R T \ln K_{P}+R T \cdot \Sigma k \cdot \ln P,
$$

де R - універсальна газова стала, 8,314 Дж/град, T- температура ванни, K, $\mathrm{K}_{\mathrm{P}}$ константа рівноваги, що має встановлену табличну залежність від температури в залежності від типу реакції [5], $\mathrm{k}$ - кількість молей газоподібних величин, Рнадмірний тиск, що діє на систему, Па. Надмірний тиск був обчислений 3 урахуванням глибини проникнення кисневих струменів, що витікали відповідно із сопел розроблюваної конструкції та порівнюваних сопел, яку було розраховано за імперично знайденим виразом [4] 


$$
L=0,72 \sqrt[3]{\left(\frac{Q \rho_{\Gamma}}{0,95 n d \rho_{M E}}\right)^{2}}\left(1-0,04 \sqrt{\frac{h_{\phi}}{d^{\prime}}}(\cos \alpha),\right.
$$

де Q - витрата продувного газу, $\mathrm{m}^{3} / \mathrm{xB} ; \rho_{\text {г }} \mathrm{i} \rho_{\text {ме }}$ - щільності газу і металу, відповідно, кг $/ \mathrm{M}^{3} ; \mathrm{n}$ - число сопел, шт; d i d'- діаметр сопел i приведений діаметр сопел (з урахуванням сумарної площі всіх сопел), м; $\mathrm{h}_{\phi}-$ положення фурми щодо металевого розплаву, м; $\alpha$ - кут нахилу сопел до вісі фурми, град. Значення величин витрати продувного газу та положення фурми були визначені методикою проведення високотемпературних досліджень пропонованого типу сопел та складали 0,2 м³/хв та 0,06 м [4].

В роботі були проаналізовані хімічні реакції, що відбуваються у первинній реакційній зоні під час продувки металевої ванни киснем зверху:

1) $1 / 2\left\{\mathrm{O}_{2}\right\}=[\mathrm{O}]$;

2) $1 / 2\left\{\mathrm{O}_{2}\right\}+[\mathrm{Fe}]=(\mathrm{FeO})$;

3) $1 / 2\left\{\mathrm{O}_{2}\right\}+[\mathrm{Mn}]=(\mathrm{MnO})$;

4) $\left\{\mathrm{O}_{2}\right\}+[\mathrm{Si}]=\left(\mathrm{SiO}_{2}\right)$;

5) $1 / 2\left\{\mathrm{O}_{2}\right\}+[\mathrm{C}]=\{\mathrm{CO}\}$;

6) $\left\{\mathrm{O}_{2}\right\}+[\mathrm{C}]=\left\{\mathrm{CO}_{2}\right\}$;

7) $1 / 2\left\{\mathrm{O}_{2}\right\}+\{\mathrm{CO}\}=\left\{\mathrm{CO}_{2}\right\}$;

8) $1 / 2\left\{\mathrm{O}_{2}\right\}+2(\mathrm{FeO})=\left(\mathrm{Fe}_{2} \mathrm{O}_{3}\right)$;

9) $1 / 2\left\{\mathrm{O}_{2}\right\}+[\mathrm{Si}]=\{\mathrm{SiO}\}$;

10) $\left\{\mathrm{O}_{2}\right\}+[\mathrm{S}]=\left\{\mathrm{SO}_{2}\right\}$;

11) $5 / 2\left\{\mathrm{O}_{2}\right\}+2[\mathrm{P}]=\left(\mathrm{P}_{2} \mathrm{O}_{5}\right)$.

Оцінка параметра енергії Гіббса для вказаних реакцій проводилася у зіставленні роботи дослідного та порівнюваного сопел шляхом отримання різниці розрахованих величин. Результат оцінки наведено на рис. 1.

Було встановлено, що при використанні складеного кільцевого сопла для вказаних вище реакцій величина енергії Гіббса має більше негативне значення, тобто вірогідність протікання реакцій у первинній реакційній зоні у порівнянні 3 варіантом використання стандартних сопел більша. Це, вірогідно, в першу чергу пов’язане 3 більшою глибиною проникнення струменя, що витікає 3 складеного кільцевого сопла, що сприяє кращому засвоєнню кисню ванною та розподілу його на основні окислювальні реакції конвертування. Причому 
International scientific and technical conference Information Technologies in Metallurgy and Machine building - ITMM 2020

найбільша різниця розрахованих величин встановлена для реакцій 4; 6; 10 та 11, що відповідають окисленню кремнію, вуглецю до вуглекислого газу та окисленню шкідливих домішок сірки та фосфору. Ці особливості кореспондуються 3 вказаними вище результатами проведених високотемпературних досліджень, на яких було встановлено у разі використання дослідного сопла біль активне протікання процесу шлакоутворення, що базується, в першу чергу, на процесі окислення кремнію. Крім того активне протікання реакцій окислення кремнію та вуглецю сприяє розвитку більш високих температур у підфурменій області, що також було зареєстровано [4]. Відмічені за результатами аналітичного дослідження кращі показники енергії Гіббса для реакцій окислення домішок сірки та фосфору потребують проведення додаткових високотемпературних досліджень 3 відбором проб металу та шлаку для визначення ступеня впливу розроблюваної конструкції сопел на рафінувальні процеси.

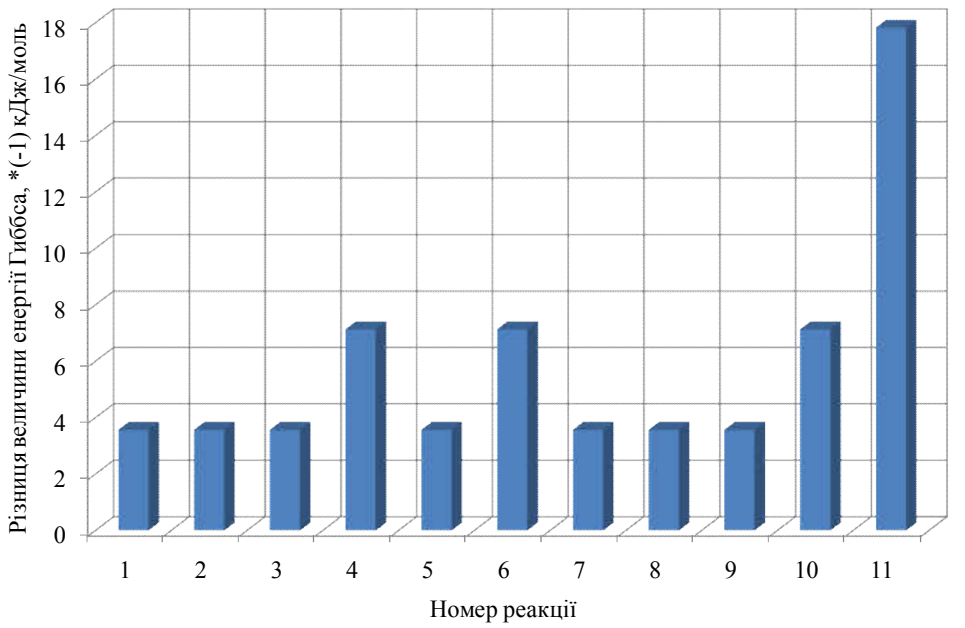

Рисунок 1 - Різниця розрахованих величин енергії Гіббса для дослідного та порівнюваного сопел для реакцій 1 - 11 (вказані в тексті)

Таким чином проведене аналітичне дослідження термодинамічного показника протікання реакцій - енергії Гіббса для умов використання складеного кільцевого сопла встановило можливість більш активного протікання всіх реакцій, що протікають у первинній реакційній зоні, а особливо реакцій, що відповідають за шлакоутворення та тепловий стан ванни. Отримані результати кореспондуються зі встановленими раніше на високотемпературних дослідах ефектами від використання пропонованого типу сопел та можуть слугувати основою для їх пояснення. 


\section{Література}

1. Бойченко Б. М. Конвертерное производство стали: теория, технология, качество стали, конструкции агрегатов, рециркуляция материалов и экология /Б. М. Бойченко, В. Б. Охотский, П. С. Харлашин. - Днепропетровск: Днепр-ВАЛ, 2006.-454 с.

2. Бигеев А. М. Металлургия стали / А. М. Бигеев. - М. : Металлургия, 1988. - 480 с.

3. Лухтура Ф. И. О степени усвоения кислорода металлической ванной при верхнем вдуве в LD-конвертере/ Ф. И. Лухтура // Вістник Приазовського державного технічного університету. Технічні науки.-2018.-вип. 36.- С. 39-53.

4. Исследование особенностей продувки через верхнюю фурму, оснащенную составным соплом на базе кольцевого коаксиального сопла / С.И.Семыкин, Т.С.Голуб, С.А.Дудченко, В.В.Вакульчук //Бюллетень научно-технической информации. Черная металургія.-2019.-т. 75.-№11.-С. 1258-1265.

5. Казачков Е.А. Расчеты по теории металлургических процессов/ Е.А. Казачков.-М.: Металлургия.- 1988. - 288 с.

\section{ANALYTICAL STUDY OF THE EFFECT OF A COMPOSITE NOZZLE DESIGN ON THE THERMODYNAMICS OF THE PROCESSES AT TOP BLOWING IN LD-CONVERTER}

\section{Golub Tetiana, Semykin Serhii}

Abstract. A complex of phenomena takes place in an oxygen-converter bath, among which the process of interaction of a gas stream of an oxidizing agent with a melt is the primary and determining factor in the passage of physical and chemical and heat-mass transfer processes during melting. In order to increase the degree of quality assimilation of oxygen by the melted bath, the use of a composite nozzle based on a coaxial annular is proposed. An analysis of the thermodynamic rate of reactions - the Gibbs energy for the conditions of use of the composite annular nozzle - has established the possibility of a more active course of all reactions occurring in the primary reaction zone. Especially reactions responsible for slag formation and the thermal state of the bath. The results obtained correspond to the effects previously established in physical and high-temperature experiments in comparison with the operation of a conventional four-nozzle tip: a deeper immersion of a gas stream in a liquid bath, active assimilation of lime, and an increase in the temperature of the sublance zone.

Key words: OXYGEN CONVERTER PROCESS, TOP BLOWING, COMPOSITE RING NOZZLE, CHEMICAL PROCESSES, GIBBS ENERGY 


\section{References}

1. Boychenko, B. M., Okhotskiy, V.B., Harlashin, P.S. (2006) Konverternoe proizvodstvo stali: teoriia, tehnologiia, kachestvo stali, konstrukcii agregatov, recirculaciia materialov $\mathrm{i}$ ekologiia, Dnepropetrovsk: Dnepr-VAL, 454 p. [in Russian].

2. Bigeev, A. M. (1988) Metallurgiia stali, Moscow: Metallurgiia, 480 p. [in Russian].

3. Lukhtura, F. I. (2018) O stepeni usvoeniia kisloroda metallicheskoy vannoy pri verhnem vduve v LD-konvertere, Vistnik Priazovskogo derzhavnogo tekhnichnogo universitetu, iss. 36, P.39-53 [in Russian].

4. Semykin, S.I., Golub, T.S., Dudchenko, S.A., Vakulchuk, V.V. (2019) Issledovaniie osobennostey produvki cherez verhniuiu furmu, osnashennuiu sostavnym soplom na baze kolcevogo koaksialnogo sopla, Biuleten nauchno-tehnicheskoy informacii. Chernaia metallurgiia, vol. 75, iss. 11, P. 1258-1265 [in Russian].

5. Kazachkov, Ye.A. (1988) Raschety po teorii metallurgicheskih processov, Moscow: Metallurgiia, 288 p [in Russian]. 